\title{
Review
}

\section{The Roles of the Virome in Cancer}

\author{
Felix Broecker ${ }^{1 *}$ and Karin Moelling ${ }^{2,3 *}$ \\ 1 Idorsia Pharmaceuticals Ltd, Hegenheimermattweg 91, CH-4123 Allschwil, Switzerland \\ 2 University of Zurich, Institute of Medical Microbiology, Gloriastr. 30, CH-8006 Zurich, Switzerland \\ 3 Max Planck Institute for molecular Genetics, Ihnestr. 63-73, 14195 Berlin, Germany \\ * Correspondence: moelling@molgen.mpg.de (KM); felixbroecker@gmx.net (FB)
}

\begin{abstract}
Viral infections as well as changes in the composition of the intestinal microbiota and virome have been linked to cancer. Moreover, the success of cancer immunotherapy with checkpoint inhibitors has been correlated with the intestinal microbial composition of patients. The transfer of feces - which contains mainly bacteria and their viruses (phages) - from immunotherapy responders to non-responders, known as fecal microbiota transplantation (FMT), has been shown to be able convert some non-responders to responders. Since phages may also increase the response to immunotherapy, for example by inducing $\mathrm{T}$ cells cross-reacting with cancer antigens, modulating phage populations may provide a new avenue to improve immunotherapy responsiveness. In this review, we summarize the current knowledge on the human virome and its links to cancer, and discuss the potential utility of bacteriophages in increasing the responder rate for cancer immunotherapy.
\end{abstract}

Keywords: virome; microbiota; cancer; bacteriophages; fecal microbiota transplantation; checkpoint inhibitors; immunotherapy

\section{Introduction - The Human Virome}

The human body hosts a large number of viruses, an estimated $10^{12}-10^{14}$ particles per individual, that collectively are termed the virome [1,2]. Despite recent progress in determining the virome, a large fraction of viral sequence data collected in virome analysis studies remain unidentified 'dark matter'. This indicates that a large number of currently unknown viruses, and their contributions to health and disease, remain to be characterized. Broadly speaking, the human virome consists of eukaryotic viruses, including pathogens that infect human cells, and viruses that infect bacteria termed bacteriophages or phages. Both human pathogenic viruses and phages have been linked to cancer, as will be discussed in this review. Other viruses that are also present in the virome, such as plant viruses (likely coming from food sources) will not be discussed here since no data is available on a possible connection to cancer. The by far largest component of the human virome are the phages, and most of them are associated with the bacteria they infect, which are most numerous in the intestinal tract that harbors about $3.8 \times 10^{13}$ bacteria per individual [3]. Here, we summarize the current knowledge on the connection of the human virome to cancer development and discuss the possibility of modulating virus and phage populations to potentially increase the responder rates to cancer immunotherapy.

\section{The Roles of the Eukaryotic Virome in Cancer}

Various eukaryotic viruses infectious to humans have been implicated in carcinogenesis inside and outside the intestinal tract, mainly those of the families Papillomaviridae and Herpesviridae as well as hepatitis viruses (Table 1). In 2012, 15.4\% of new cancers (2.2 million cases) worldwide were attributed to carcinogenic infections [4], most frequently with the bacterium Helicobacter pylori (770,000 cases) followed by 640,000 cases linked to human papillomavirus (HPV), 420,000 and 170,000 cases linked to hepatitis $B$ and $C$ virus (HBV and HCV), respectively, and 120,000 associated with Epstein-Barr virus (EBV, also 
known as human herpesvirus 4, HHV4). Of note, infections with these viruses does not necessarily lead to cancer. Rather, they often are one of many contributing factors to carcinogenesis. As such, virus-associated cancers typically develop as part of persistent infections over many years [5]. The proposed mechanisms of viral contributions to carcinogenesis also vary widely between viral species and will be briefly discussed in the following subsections. In general, viral infections can contribute to carcinogenesis by any of the following mechanisms: insertional mutation in the host genome, induction of inflammation and modulation of signaling pathways in the infected cells, for example, by viral oncogenes [6,7] (Figure 1A).

Table 1. Eukaryotic viruses linked to cancer. Abbreviations: ATLL, adult T-cell leukemia/lymphoma; BKV; BK polyomavirus; CMV, cytomegalovirus; CTCL, cutaneous T-cell lymphoma; DLBCL, diffuse large B-cell lymphoma; EBV, Epstein-Barr virus; HBoV; human bocavirus; HBV, hepatitis B virus; HCC, hepatocellular carcinoma; HCV, hepatitis C virus; HHV, human herpesvirus; HIV, human immunodeficiency virus; HPV, human papillomavirus; HSV, herpes simplex virus; HTLV-1, human T-lymphotropic virus type 1; JCV, JC polyomavirus; KSHV, Kaposi sarcoma-associated herpesvirus; MCV, Merkel cell polyomavirus; NHL, non-Hodgkin lymphoma; PTCL, peripheral T-cell lymphoma; SCC, squamous cell carcinoma; TTV, torque teno virus.

\begin{tabular}{|c|c|c|c|}
\hline Virus family & Virus & Cancer type & Observations \\
\hline \multirow{11}{*}{ Papillomaviridae } & $\mathrm{HPV}$ & Anal & $\begin{array}{l}\mathrm{HPV} \text { is a possible risk factor for anal and rectal cancer }[8,9] \text { and a sig- } \\
\text { nificant prognostic marker, especially for locally advanced disease }[10]\end{array}$ \\
\hline & HPV & Bladder & HPV may be linked to bladder cancer in a small number of cases [11] \\
\hline & HPV & Cervical & $\begin{array}{l}\text { Association between infection with high-risk HPV serotype (mainly } \\
\text { HPV-16 and -18) and development of cervical cancer [11-13] }\end{array}$ \\
\hline & $\mathrm{HPV}$ & Colorectal & $\begin{array}{l}\text { HPV is a possible risk factor for colorectal cancer }[14,15] \text {, however, an- } \\
\text { other study found no association }[16]\end{array}$ \\
\hline & HPV & Esophageal & $\begin{array}{l}\text { HPV-16 is a risk factor for esophageal carcinoma }[17,18] ; \text { HPV infection } \\
\text { is common in esophageal carcinoma [19] }\end{array}$ \\
\hline & HPV & $\begin{array}{l}\text { Head and neck } \\
\quad(\mathrm{SCC})\end{array}$ & $\begin{array}{c}\text { HPV infection is associated with head and neck cancer }[11,20,21] \text { and } \\
\text { better long-term outcome }[22]\end{array}$ \\
\hline & HPV & Oral & Association of HPV-6 with oral cancer [23] \\
\hline & HPV & Prostate & Association of HPV-16 with prostate cancer [24] \\
\hline & HPV & Renal & Association of HPV-16, -18 and -58 with renal cell carcinoma [25] \\
\hline & HPV & Skin and mucosal & $\begin{array}{l}\text { Papillomavirus DNA frequently detected in skin- and mucosa-associ- } \\
\text { ated cancers [26]; HPV-5 and -8 are associated with epidermodysplasia } \\
\text { verruciformis associated with a high risk of skin cancer }[27,28]\end{array}$ \\
\hline & HPV & Vulvar & Association between HPV and vulvar squamous cell carcinoma [29] \\
\hline \multirow{8}{*}{ Herpesviridae } & CMV (HHV5) & Colorectal & $\begin{array}{l}\text { CMV DNA is more abundant cancer tissues compared to healthy tis- } \\
\text { sues [30]; CMV-positive tumors in non-elderly patients are associated } \\
\text { with increased disease-free survival rate [31]; specific genetic polymor- } \\
\text { phisms of CMV are linked to different clinical outcomes [32] }\end{array}$ \\
\hline & EBV (HHV4) & Colorectal & $\begin{array}{l}\text { Possible association of EBV with colorectal carcinoma [33], however, } \\
\text { no association found in another study [16] }\end{array}$ \\
\hline & EBV (HHV4) & Esophageal & EBV is associated with esophageal cancer [34] \\
\hline & & & Possible involvement of EBV in gastric cancer and precursor lesions \\
\hline & EBV (HHV4) & Gastric & $\begin{array}{c}\text { [35]; patients with EBV-positive gastric cancer had a better response to } \\
\text { chemotherapy and better survival [36] }\end{array}$ \\
\hline & EBV (HHV4) & Hepatic & EBV infections detected in HCC tissues [37] \\
\hline & EBV (HHV4) & $\begin{array}{l}\text { Lymphoma } \\
\text { (DLBCL) }\end{array}$ & EBV RNA detected in B-cell lymphoma samples [38] \\
\hline & EBV (HHV4) & Lymphoma (PTCL) & $\begin{array}{l}\text { EBV expression associated with some subtypes of peripheral T-cell } \\
\text { lymphomas [39] }\end{array}$ \\
\hline
\end{tabular}




\begin{tabular}{|c|c|c|c|}
\hline & EBV (HHV4) & Oral & $\begin{array}{l}\text { Higher proportion of EBV-positive oral squamous cell carcinoma in in- } \\
\text { dustrialized countries [40] }\end{array}$ \\
\hline & EBV (HHV4) & Skin and mucosal & EBV DNA frequently detected in skin and mucosal cancers [26] \\
\hline & HHV6 & $\begin{array}{l}\text { Lymphoma } \\
\text { (DLBCL) }\end{array}$ & HHV6 RNA detected in B-cell lymphoma samples [38] \\
\hline & HHV6 & $\begin{array}{l}\text { Malignant mela- } \\
\text { noma }\end{array}$ & HHV6 DNA frequently detected in malignant melanoma [26] \\
\hline & HHV7 & Bladder & HHV7 DNA frequently detected in bladder cancer [26] \\
\hline & HHV7 & Lymphoma (CTCL) & $\begin{array}{l}\text { HHV7 DNA frequently detected in cutaneous T-cell lymphoma (Myco- } \\
\text { sis fungoides) [26] }\end{array}$ \\
\hline & HHV7 & Oral & HHV7 DNA frequently detected in oral cavity cancer [26] \\
\hline & HSV (HHV1/2) & Oral & $\begin{array}{l}\text { Higher proportion of HSV-positive oral squamous cell carcinoma in in- } \\
\text { dustrialized countries [40] }\end{array}$ \\
\hline & KSHV (HHV8) & Kaposi sarcoma & $\begin{array}{l}\text { In HIV-infected individuals, KSHV infection is associated with Kaposi } \\
\text { sarcoma [41] }\end{array}$ \\
\hline & BKV & Bladder & Possible association of BKV with bladder cancer [26] \\
\hline & BKV & Colorectal & $\begin{array}{l}\text { Possible association of BKV with colorectal cancer }[42,43] \text {, however, } \\
\text { other studies found no association }[16,44]\end{array}$ \\
\hline Polyomaviridae & $\mathrm{JCV}$ & Colorectal & $\begin{array}{l}\text { JCV is associated with colorectal cancer }[44,45] \text { and may be involved in } \\
\text { carcinogenesis [46], specifically in chromosomal instability [47]; JCV T- } \\
\text { antigen is expressed in early stage colorectal cancer [48], however, an- } \\
\text { other study found no association [16] }\end{array}$ \\
\hline & $\mathrm{MCV}$ & $\begin{array}{l}\text { Merkel cell carci- } \\
\text { noma }\end{array}$ & $\mathrm{MCV}$ is the major causative factor for Merkel cell carcinoma $[49,50]$ \\
\hline & HIV & Anal & $\begin{array}{l}\text { HIV-positive people have increased risk for anal cancer }[51,52] \text { and } \\
\text { worse overall colostomy-free survival rates }[53]\end{array}$ \\
\hline & HIV & Cervical & $\begin{array}{l}\text { Cervical cancer is more prevalent in HIV-positive individuals, likely } \\
\text { because of increased susceptibility to HPV infection }[54,55]\end{array}$ \\
\hline Retroviridae & HIV & Kaposi sarcoma & $\begin{array}{l}\text { Kaposi sarcoma is more prevalent in HIV-positive individuals, likely } \\
\text { because of increased susceptibility to KSHV infection }[54,55]\end{array}$ \\
\hline & HIV & Lymphoma (NHL) & $\begin{array}{l}\text { Aggressive B cell non-Hodgkin lymphoma is more prevalent in HIV- } \\
\text { positive individuals, likely because of increased susceptibility to EBV } \\
\text { infection }[54,55]\end{array}$ \\
\hline & HTLV-1 & Lymphoma (ATLL) & $\begin{array}{l}\text { HTLV-1 induces adult T-cell leukemia/lymphoma in } 5 \% \text { of infected in- } \\
\text { dividuals [56] through random integration into the host genome [57] }\end{array}$ \\
\hline & HBV & Bile duct & HBV is a risk factor for bile duct cancer [58] \\
\hline & $\mathrm{HBV}$ & Colorectal & Chronic HBV infection is a risk factor for colorectal cancer [59] \\
\hline & $\mathrm{HBV}$ & Hepatic & Liver cancer is associated with HBV [11] \\
\hline & $\mathrm{HBV}$ & Pancreatic & $\begin{array}{c}\text { Chronic HBV infection [60] or past exposure [61] are risk factors for } \\
\text { pancreatic cancer }\end{array}$ \\
\hline & $\mathrm{HCV}$ & Bile duct & HCV is a risk factor for bile duct cancer [58] \\
\hline & $\mathrm{HCV}$ & Hepatic & Liver cancer is associated with HCV [11] \\
\hline tho & TTV & Hepatic & TTV is a risk factor for hepatocellular carcinoma [62] \\
\hline ther & $\mathrm{HBoV}$ & Colorectal & Some colorectal cancers are associated with HBoV [63] \\
\hline & $\mathrm{HBoV}$ & Lung & Some lung cancers are associated with $\mathrm{HBoV}$ [63] \\
\hline & $\mathrm{HBoV}$ & Tonsillar & Association of $\mathrm{HBoV}$ with tonsil squamous cell carcinoma [64] \\
\hline & $\begin{array}{l}\text { Orthobunya- } \\
\text { viruses }\end{array}$ & Colorectal & High abundance of orthobunyaviruses in colorectal cancer [65] \\
\hline & Parvoviruses & Skin & Parvovirus DNA frequently detected in skin-associated cancers [26] \\
\hline & Anelloviruses & Mucosal & Anellovirus DNA frequently detected in mucosal cancers [26] \\
\hline & Anelloviruses & Leukemias & Anellovirus DNA frequently detected in leukemias [26] \\
\hline
\end{tabular}




\subsection{Papillomaviridae}

Papillomaviridae is a family of non-enveloped viruses with double-stranded DNA genomes [66]. Members infectious to humans, HPV, have been linked to various cancers, most significantly cervical cancer [11-13]. However, only a subset of the 150 types of $\mathrm{HPV}$, the so-called high-risk types such as HPV-16 and -18, are typically linked to cancer [67]. The main proposed mechanism of contribution of high-risk HPV to cervical cancer is through integration of the viral DNA into the host genome and expression of viral oncogenes. It has been shown, for example, that the E6 and E7 early oncogenes degrade tumor suppressors $\mathrm{p} 53$ and retinoblastoma protein $(\mathrm{pRb})$, which among other effects cause the cell to arrest in the S-phase [68]. It is thought that a similar mechanism is also at work in other HPV-associated cancers such as colorectal cancer [69]. HPV is the most frequently sexually transmitted infectious agent in the United States, and vaccines against HPV are recommended for all girls aged 11 to 12 years, aiming to reduce the burden of cervical cancer [70]. HPV has also been identified as a potential risk factor for various other cancer types, including anal [9,10], bladder [11] colorectal [14,15] esophageal [17-19], head and neck [11,20,21], oral [23], prostate [24], renal [25], skin/mucosal [26-28] and vulvar cancer [29]. In most of these cases, however, the association with HPV is not as strong as for cervical cancer, or is only seen in subsets of patients, and consequently there is also conflicting data. For example, a study from 2014 found no link between HPV infection and colorectal cancer [16]. In addition, there is an established correlation between HPV infection and head and neck cancer $[11,20,21]$, but also data indicating that the presence of HPV in head and neck tumors predicts better long-term clinical outcome [22]. Moreover, merely associating the presence of specific viral sequences with cancer status does not necessarily indicate a causal role of the virus.
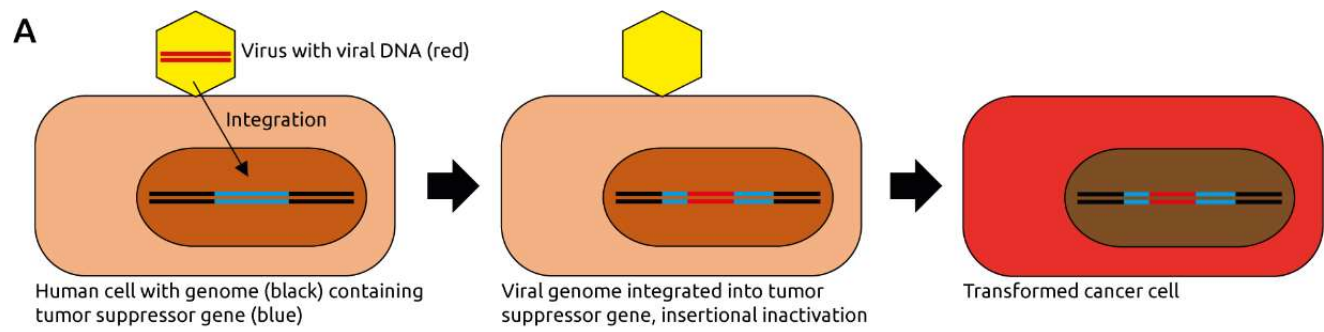

B

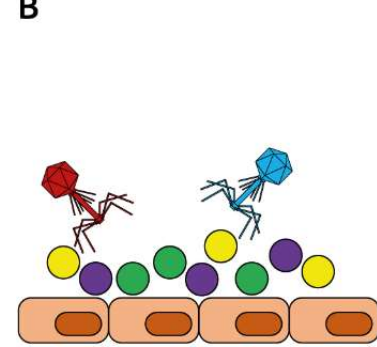

Bacteria and phages coexist in healthy equilibrium (eubiosis)

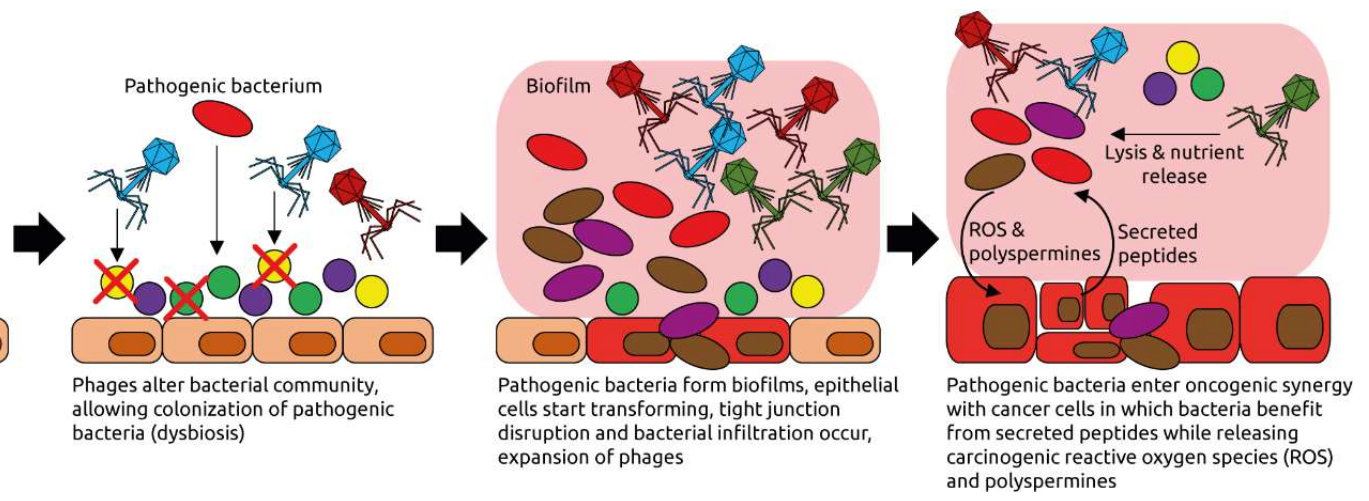

and polyspermines

Figure 1. Examples of virus-induced carcinogenesis. (A) A eukaryotic virus infects a human cell and integrates its genome into the host cell genome. In this example, the viral genome integrates into and thereby inactivates a tumor suppressor gene, contributing to oncogenic transformation. The viral genome may also express viral oncogenes, or it activates a near-by host proto-oncogene (not shown). Figure adapted from Marônek et al. [7]. (B) Phages coexist with their host bacteria in a well-balanced equilibrium, for example in the intestinal tract. Some phages might get activated pathologically and alter the bacterial community structure through lysis. Pathogenic bacteria can then thrive and form biofilms. Phages populations expand, typical for dysbiotic, intestinal microbiota and inflammation [71]. Phages lyse commensal bacteria, releasing nutrients that are used by the pathogenic ones. Reactive oxygen species 
(ROS) and polyspermines produced in the biofilms contribute to DNA damage of host cells, and thereby oncogenic transformation [72]. Peptides released by the transformed cells are metabolized by the pathogenic bacteria. Figure adapted from Hannigan et al. [73].

\subsection{Herpesviridae}

Viruses of the Herpesviridae family are enveloped dsDNA viruses infecting mammals, birds and reptiles [74]. Various members have been implicated in cancer formation, including cytomegalovirus (CMV, also known as human herpesvirus 5, HHV5), EpsteinBarr virus (EBV or HHV4), herpes simplex virus (HSV or HHV1/2) and HHV6 and HHV7 (Table 1). The strongest association with cancer has been reported for EBV, which has been linked to colorectal carcinoma (CRC) [33] (although a later study found no association [16]), esophageal [34] and gastric cancer [35] (interestingly, however, patients with EBV-positive gastric cancer had a better response to chemotherapy and better survival [36]), hepatocellular carcinoma [37], lymphoma [38,39], oral [40], as well as skin and mucosa associated cancers [26]. Therefore, it has been proposed that vaccination against EBV might be a viable means to prevent EBV-associated cancers [75]. Various EBV vaccine candidates are currently in preclinical or clinical development.

CMV has been linked to colorectal cancer [30], however, in non-elderly patients CMV-positive tumors have been associated with increased disease-free survival rate [31]). HHV6 was found to be connected to malignant melanoma [26] and B-cell lymphoma [38], HHV7 to bladder and oral cancer as well as to T-cell lymphoma [26], and HSV has been associated with oral cancer [40].

In HIV-infected individuals, Kaposi sarcoma-associated herpesvirus (KSHV) infection is associated with Kaposi sarcoma [41].

Mechanistically, herpesviruses such as CMV and HSV are known to induce DNA synthesis and counteract apoptosis via activation of the Ras/Raf-1/MEK/ERK pathway [69]. In addition, KSHV has been shown to inhibit tumor suppressor protein p53 [76].

\subsection{Polyomaviridae}

Two members of the Polyomaviridae family (non-enveloped dsDNA viruses), namely BKV and JCV, have been linked to CRC [42,43,45-48]. However, other studies have challenged this notion and found no link $[16,44]$. There is also a possible association of BKV with bladder cancer [26]. The clearest evidence, however, has been obtained for Merkel cell polyomavirus (MCV) that has been identified as a major causative factor for Merkel cell carcinoma $[49,50]$. Consequently, it has been proposed that an anti-MCV vaccine might help to prevent Merkel cell carcinoma [77,78].

It has been hypothesized that MCV contributes to oncogenesis in two steps: integration of the viral genome into the host genome followed by mutational truncation of the large $\mathrm{T}$ antigen gene [79]. The truncated $\mathrm{T}$ antigen promotes cell cycle progression. The $\mathrm{T}$ antigen likely also plays a role in oncogenic transformation mediated by other polyomaviruses such as BKV and JCV.

\subsection{Retroviridae}

The retroviruses human immunodeficiency virus (HIV) and human T-lymphotropic virus type 1 (HTLV-1) have both been associated with cancer. Three HIV-associated cancers are known, cervical cancer, aggressive B cell non-Hodgkin lymphoma and Kaposi sarcoma [54,55]. In addition, HIV infection has been linked to an increased risk for anal cancer [51,52] and worse overall colostomy-free survival rates [53]. The effect of HIV infection is likely indirect; the virus weakens the immune system and renders infected individuals more susceptible to infections by other viruses, such as Kaposi sarcoma-associated herpesvirus (KSHV), which has been linked to Kaposi sarcoma [41]. For HTLV-1, oncogenesis is thought to involve multiple mechanism [80]. These include: (1) the establishment of a persistent infection that results in chronic inflammation, which attracts phagocytes that release reactive oxygen species, contributing to DNA damage, (2) the genomic integration 
and expression of viral oncogenes, such as the Tax-1 protein that, among other functions, inhibits tumor suppressor p53, and (3) the suppression of host immune responses.

\subsection{Other Viruses}

Various other viruses have been linked to cancer. Among these are the hepatitis viruses HBV and HCV. HBV (family Hepadnaviridae with dsDNA genome and an envelope) infects the liver and has been linked to liver cancer [11] but may also be a risk factor for cancers of the bile duct [58], the colon [59] and the pancreas [60,61]. HCV (an enveloped ssRNA virus of the Flaviviridae family) also infects the liver and has been associated with liver and bile duct cancer [11,58]. Liver carcinogenesis by HBV and HCV is multifactorial and has been linked, amongst others, to virus-induced changes in signaling pathways and the inflammatory status $[81,82]$. Anelloviruses (circular ssDNA viruses) including torque teno virus (TTV) have been associated with hepatic [62] and mucosal [26] cancer as well as leukemias [26]. Human bocavirus $(\mathrm{HBoV})$ and other members of the Parvoviridae family (ssDNA viruses) have been linked to various cancers, including colorectal and lung cancer [63], squamous cell carcinoma [64] and skin cancer [26]. The ssRNA orthobunyaviruses may be linked to colorectal cancer [65]. The mechanisms of oncogenesis of anelloviruses, parvoviruses and orthobunyaviruses remain largely unknown.

\section{The Human Intestinal Virome and its Links to Cancer}

The human intestinal microbiota is a complex community of bacteria, archaea, viruses, fungi, and eukaryotic parasites [83]. Collectively, the microbes outnumber human cells. The human body contains about $3 \times 10^{13}$ human cells and $3.8 \times 10^{13}$ bacteria [3], and bacterial genes $(\sim 2,000,000)$ are estimated to be about 100 times more numerous than human genes $(20,000)$ [84]. Viruses, predominantly phages, are likely the most abundant biological entities, with an estimated number of $10^{15}$ in the human gastrointestinal tract [85]. Other community members such as archaea of fungi are substantially less abundant. Collectively, one could take the view that we are symbionts of host and microbial cells, each with their own set of genes. The gut microbiota plays important roles in food digestion, development of the immune system and protection against microbial pathogens. Pathological changes in the microbial composition (dysbiosis), induced by infections, chronic diseases, or antibiotic treatment, can lead to failure of control of pathogens and severe damage as in inflammatory bowel disease (IBD). Dysbiosis is also observed in extra-intestinal diseases such as asthma or autism [86].

The composition of the human virome is largely unknown. A recent study described a catalog of tens of thousands of viruses from human metagenomes, which revealed associations with chronic diseases [87]. This study describes 45,000 unique viruses as part of the human microbiota, and about 2,000 specific phages were found to correlate with a variety of common chronic diseases such as Parkinson's disease and obesity. All bacteria are infected by phages, which play a role in maintaining the bacterial population in healthy individuals. Depending on environmental conditions and the genetic composition of the phages, they can lyse their bacterial hosts. In the oceans where bacteria and phages are very abundant lysis occurs in about $20 \%$ of the bacteria in about 24 hours [88]. The virome may regulate the microbiome and may influence bacterial complexity, whereby the population dynamics likely follow a 'kill-the-winner' ecological model. In this model, the most abundant bacteria are killed by their phages, other bacterial taxa will take over the ecological niche and be subsequently killed by their phages [88]. Thereby, phages play a crucial role and shaping the composition of the intestinal bacterial communities. They also facilitate horizontal gene transfer and thereby the functional capacity of the microbiota [88]. The virome is more challenging to study and to characterize than bacterial populations, and many of its contributions to ecosystems are still poorly understood. Many of the viruses are unknown, sometimes designated as 'viral dark matter' [89]. 
Changes in the fecal virome, especially the phage population, have been reported recently for CRC patients $[7,65,73,90]$. It has been suggested that phages may play a causative role in $\mathrm{CRC}$ by altering the bacterial populations of the intestine such that pathogenic bacteria can thrive and form biofilms [72,73] (Figure 1B). Several phage species have been linked to CRC $[65,69]$. Comparing the fecal microbiota of CRC patients to healthy controls, specific phages have been found to be more abundant in patients that could play a role in shifting the overall bacterial populations or serve as biomarkers. Phage SpSL1, for example, infects bacteria of the Streptococcus genus and was found to be more abundant in earlystage CRC than in controls but its abundance decreased in later stages [65]. Depletion of commensal Escherichia coli bacteria by various phages whose abundance increases during CRC, including Enterobacteria phage HK544, Punalikevirus, Lambdalikevirus and Mulikevirus, may contribute to the disease-associated dysbiosis [65]. However, it remains unknown if phages have a causal role in the development of dysbiosis, or whether their increased abundance is a consequence of dysbiosis. The observed differences, however, might serve as a starting point for targeted microbiota manipulations aiming to reverse the dysbiosis, which may have a positive impact on treatment.

\section{Fecal Microbiota Transplantation - Focus on Viruses and Cancer}

Infections by drug resistant bacteria such as Clostridioides difficile have reactivated a historic therapy, the transfer of healthy fecal microbiota into the intestine of patients with dysbiotic diseases. This procedure has been applied in China already in the $4^{\text {th }}$ century, sometimes designated as "golden soup" from fermented feces, some Bedouin tribes cured dysentery by consuming healthy camel dung and in farm animals the transfer of healthy bacteria from cows known as transfaunation has been established centuries ago [91,92].

In recent years the procedure was resumed and widely applied, mostly to cure recurrent $C$. difficile infections due to impressive cure rates for recurrent disease of about $90 \%$ or higher [91]. We described such a case of a patient in Zurich, Switzerland who received fecal material from a healthy donor and recovered without adverse events, meanwhile healthy for almost ten years [93]. An indicator of successful therapy is the diversity of the microbiota, which is higher and different in composition in healthy people than in C. difficile patients where it is diminished due to antibiotic therapy. An estimated 15,000 to 30,000 people die of this infection in the United States annually [94].

FMT may be adaptable to other indications, including obesity whose severity often correlates with low complexity of the intestinal microbiota, but convincing clinical data is still lacking [95]. FMT can also be applied in the form of gastric acid resistant pills [96], and selections of specific bacteria [97] as well as probiotic supplements [98] show some degree of efficacy against recurrent $C$. difficile infections. Also, some recent data suggest that sterile fecal filtrate in which bacteria have been removed can effectively cure $C$. difficile infections $[99,100]$. Moreover, successful FMT was associated with the stable transfer of phages from donor to recipient [101-103]. We have shown that a core virome comprising the most dominant phage species, is transmitted during FMT and stabilizes in the recipient before the bacterial populations do [102]. These studies indicate that phages might be sufficient in conferring the beneficial effects of FMT, although a contribution of metabolites, proteins and bacterial fragments present in the filtrate cannot be excluded.

The composition of the intestinal microbiota has recently been shown to contribute to the success of anticancer therapy with checkpoint inhibitors [104]. The new immunotherapy has a $20-40 \%$ response rate, but in the remaining patients the therapy has virtually no effect [105]. How to cure the remaining $60-80 \%$ is one of the most urgent research topics. The microbiota likely plays a role. It has been shown recently that FMT using donor stool from responders can boost the response to checkpoint inhibitor therapy of previous non-responder melanoma patients [106,107]. Conversely, antibiotic therapy, which disrupts the intestinal microbiota, correlates with poor outcome of checkpoint inhibitor therapy [108]. 
Immunotherapies have been tried for about 100 years. The surgeon William B. Coley (1862-1936) observed that patients with an unrelated bacterial infection or receiving bacterial toxins (the so-called Coley's toxins) after surgery had a stronger antitumor response than those without infection $[109,110]$. Coley treated patients with streptococcal bacteria and reported some good results but sometimes variable success and was therefore controversial.

Germ-free or antibiotic-treated mice with depleted intestinal bacteria serve as animal models for the effects of the microbiota of responders and non-responders [104]. Indeed, instilling microbiota from responders transferred a "responder" phenotype to mice, whereas transfer from non-responders rendered mice non-responsive [111-114]. The comparison of stool samples from responders and non-responders revealed certain bacterial species whose presence or abundance correlated with successful treatment. This included, among others, Faecalibacterium prausnitzii, Akkermansia muciniphila, Bifidobacterium longum and Bacteroides caccae, depending on the type of cancer [111-115].

Stool transfer from a responder can help to convert a non-responder into a responder. This was shown recently by two studies [106,107]. Davar et al. [106] performed FMT on 15 non-responding patients with malignant melanoma using donor stool from responders. Six of the 15 patients showed objective responses to pembrolizumab (anti-PD-1 receptor monoclonal antibody) following the procedure. There were also no severe side effects. Bacteria associated with clinical response were, among others, Bifidobacterium longum, Colinsella aerofaciens and Faecalibacterium prausnitzii, enriched were mostly bacteria of the Firmicutes phylum (Ruminococcaceae and Lachnospiraceae families). Also, response to therapy correlated with a specific subset of $\mathrm{T}$ cells with cytolytic function (CD56 ${ }^{+} \mathrm{CD} 8^{+} \mathrm{T}$ cells) and decreased interleukin- 8 expressing myeloid cells. Some of the above-mentioned bacteria were confirming earlier observations [106]. Thus, a single FMT helped to overcome primary resistance to immunotherapy in a subset of melanoma patients. Why there were still so many non-responders, nine out of 15 , remains unclear. By all means the patients should not have undergone recent treatments with antibiotics, which is known to counteract the therapeutic success [108].

In a similar study, ten patients with anti-PD-1 refractory metastatic melanoma received FMT with donor stool from responders followed by reintroduction of anti-PD-1 immunotherapy [107]. Two partial responses and one complete remission were observed. Recipients of the FMT were eligible for FMT if they had progressed on at least one line of anti-PD-1 therapy. Patients first underwent a microbiota depletion phase with antibiotic therapy for 72 hours (vancomycin, neomycin). They received oral stool capsules for FMT every two weeks for 90 days and anti-PD-1 therapy (nivolumab). No clear-cut microbiota indicative for responders was determined. The safety of FMT was confirmed and recommended. Antibiotic therapy was effective as pre-FMT protocol and was intended to allow for a better engraftment of the transferred microbiota.

Of note, the viromes of responders and non-responders so far have not been analyzed, so it remains unclear if there are certain phage species or eukaryotic viruses that correlate with successful treatment. However, it has been shown recently that a phagespecific T cell epitope corresponded with PD-1 responsiveness in mice [116]. This T cell epitope has been proposed to induce memory $\mathrm{T}$ cells cross-reacting with a tumor antigen. This opens up the avenue that certain phage species could be used therapeutically stimulate the immune system to enhance the efficacy of immunotherapy. Moreover, the microbiota of responders may contain such phage species which active $\mathrm{T}$ cells that are crossreactive to tumor antigens; phage species that may be absent in non-responders. Modulating phage populations of non-responders may therefore be a promising avenue to increase responsiveness to immunotherapy. Eukaryotic viruses may also contribute to the responsiveness to immunotherapy through their known roles in modulating the immune system [117]. Virome analyses of responders and non-responders are warranted to identify such phages and viruses. 


\section{Conclusions and Outlook}

Carcinogenesis is a multifactorial process that involves genetic and environmental factors, the microbiota, and the virome [118] (Figure 2). Both eukaryotic viruses and phages can contribute to cancer formation and progression, as discussed herein, through various mechanisms. Of note, we are only beginning to understand the complexity of the human virome, and new viruses will be discovered in the 'dark matter' of so far unknown virus-like sequences generated during virome analyses. These may include viruses that contribute to cancer that we may, for instance, ingest with our food [119], or the more recently discovered giant viruses including Mimiviridae and Phycodnaviridae whose oncogenic potential may be underestimated [120,121]. Knowing the identity of potential oncogenic viruses would provide the opportunity for intervention and vaccination approaches, that have already been implemented for HPV to prevent cervical cancer. The virome may also play a role in the response of patients to cancer immunotherapy with checkpoint inhibitors; similar to beneficial bacterial taxa that correlate with response to treatment, beneficial viruses and phages may be identified. In particular, phages may be crucial in mediating the effects of FMT, a therapeutic intervention has shown promise to 'convert' non-responders to immune therapy to responders $[106,107]$. We and others have shown that during FMT, phages are transmitted [101-102,122]. In some indications, sterile fecal filtrates (containing phages, but not bacteria) may even be more efficient than FMT, as shown recently for necrotizing enterocolitis of preterm infants [123]. The role of phages (and eukaryotic viruses) in determining the responder status to immunotherapy has not been investigated to date. This knowledge may help to improve response rates for cancer immunotherapy by targeted supplementation and modulation of the patients' phageomes and viromes.

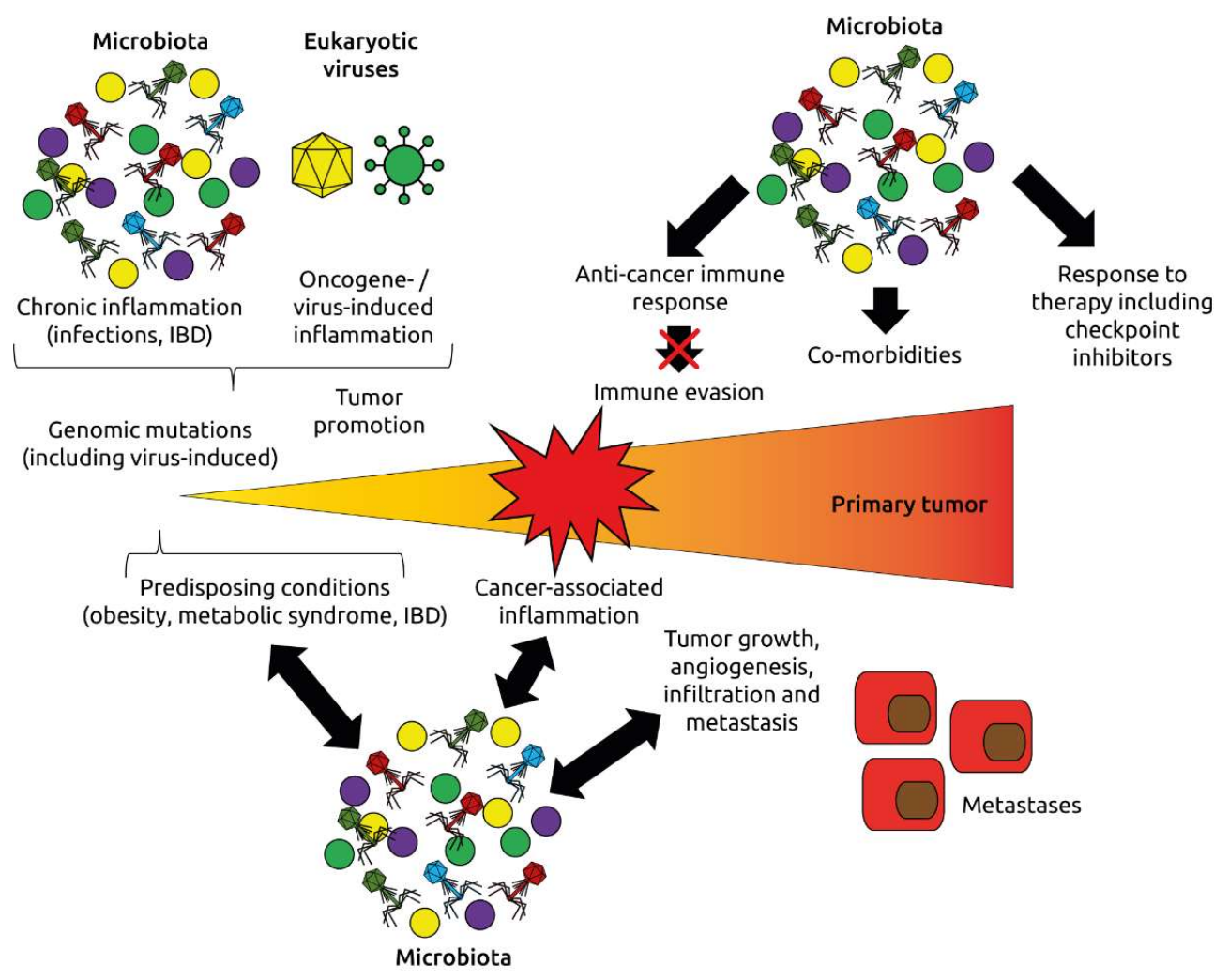

Figure 2. Roles of the microbiota and virome (eukaryotic viruses and phages) in oncogenesis and response to immunotherapy. The microbiota and virome affect inflammation, one of the hallmarks of cancer, the development of cancer-promoting conditions like obesity, metabolic syndrome and 
inflammatory bowel disease (IBD), and modulate immune mechanisms regulating cancer initiation and progression. Adapted from Dzutsev et al. [118].

Author Contributions: K.M. and F.B. wrote the manuscript and have read and agreed to the published version of the manuscript.

Funding: This research received no external funding.

Conflicts of Interest: The authors declare no conflict of interest.

\section{References}

1. Shkoporov, A.N.; Hill, C. Bacteriophages of the Human Gut: The "Known Unknown" of the Microbiome. Cell Host Microbe 2019, 25, 195-209.

2. Liang, G.; Bushman, F.D. The human virome: assembly, composition and host interactions. Nat. Rev. Microbiol. 2021, 19, 514527.

3. Sender, R.; Fuchs, S.; Milo, R. Revised Estimates for the Number of Human and Bacteria Cells in the Body. PLoS Biol. 2016, 14, e1002533.

4. Plummer, M.; de Martel, C.; Vignat, J.; Ferlay, J.; Bray, F.; Franceschi, S. Global burden of cancers attributable to infections in 2012: a synthetic analysis. Lancet Glob. Health 2016, 4, e609-16.

5. Mesri, E.A.; Feitelson, M.A.; Munger, K. Human viral oncogenesis: a cancer hallmarks analysis. Cell Host Microbe 2014, 15, 26682.

6. Zhang, L.L.; Wie, J.Y.; Wang, L.; Huang, S.L.; Chen, J.L. Human T-cell lymphotropic virus type 1 and its oncogenesis. Acta Pharmacol. Sin. 2017, 38, 1093-1103.

7. Marônek, M.; Link, R.; Monteleone, G.; Gardlík, R.; Stolfi, C. Viruses in Cancers of the Digestive System: Active Contributors or Idle Bystanders? Int. J. Mol. Sci. 2020, 21, 8133.

8. Lui, R.N.; Tsoi, K.K.F.; Ho, J.M.W.; Lo, C.M.; Chan, F.C.H.; Kyaw, M.H.; Sung, J.J.Y. Global Increasing Incidence of YoungOnset Colorectal Cancer Across 5 Continents: A Joinpoint Regression Analysis of 1,922,167 Cases. Cancer Epidemiol. Biomarkers Prev. 2019, 28, 1275-1282.

9. Muresu, N.; Sotgiu, G.; Saderi, L.; Sechi, I.; Cossu, A.; Marras, V.; Meloni, M.; Martinelli, M.; Cocuzza, C.; Tanda, F.; Piana, A. Distribution of HPV Genotypes in Patients with a Diagnosis of Anal Cancer in an Italian Region. Int. J. Environ. Res. Public Health 2020, 17, 4516

10. Kabarriti, R.; Brodin, N.P.; Ohri, N.; Narang, R.; Huang, R.; Chuy, J.W.; Rajdev, L.N.; Kalnicki, S.; Guha, C.: Garg, M.K. Human papillomavirus, radiation dose and survival of patients with anal cancer. Acta Oncol. 2019, 58, 1745-1751.

11. Cantalupo, P.G.; Katz, J.P.; Pipas, J.M. Viral sequences in human cancer. Virology 2018, 513, 208-216.

12. de Sanjose, S.; Quint, W.G.; Alemany, L.; Geraets, D.T.; Klaustermeier, J.E.; Lloveras, B.; Tous, S.; Felix, A.; Bravo, L.E.; Shin, H.R.; Vallejos, C.S.; de Ruiz, P.A.; Lima, M.A.; Guimera, N.; Clavero, O.; Alejo, M.; Llombart-Bosch, A.; Cheng-Yang, C.; Tatti, S.A.; Kasamatsu, E.; Iljazovic, E.; Odida, M.; Prado, R.; Seoud, M.; Grce, M.; Usubutun, A.; Jain, A.; Suarez, G.A.; Lombardi, L.E.; Banjo, A.; Menéndez, C.; Domingo, E.J.; Velasco, J.; Nessa, A.; Chichareon, S.C.; Qiao, Y.L.; Lerma, E.; Garland, S.M.; Sasagawa, T.; Ferrera, A.; Hammouda, D.; Mariani, L.; Pelayo, A.; Steiner, I.; Oliva, E.; Meijer, C.J.; Al-Jassar, W.F.; Cruz, E.; Wright, T.C.; Puras, A.; Llave, C.L.; Tzardi, M.; Agorastos, T.; Garcia-Barriola, V.; Clavel, C.; Ordi, J.; Andújar, M.; Castellsagué, X.; Sánchez, G.I.; Nowakowski, A.M.; Bornstein, J.; Muñoz, N.; Bosch, F.X.; Retrospective International Survey and HPV Time Trends Study Group. Human papillomavirus genotype attribution in invasive cervical cancer: a retrospective cross-sectional worldwide study. Lancet Oncol. 2010, 11, 1048-1056.

13. Clifford, G.; Franceschi, S. ; Diaz M, Muñoz N, Villa LL. Chapter 3: HPV type-distribution in women with and without cervical neoplastic diseases. Vaccine 2006, 24 Suppl 3, S3/26-34.

14. Kirgan, D.; Manalo, P.; Hall, M.; McGregor, B. Association of human papillomavirus and colon neoplasms. Arch. Surg. 1990, $125,862-865$.

15. Lee, Y.M.; Leu, S.Y.; Chiang, H.; Fung, C.P.; Liu, W.T. Human papillomavirus type 18 in colorectal cancer. J. Microbiol. Immunol. Infect. 2001, 34, 87-91.

16. Fiorina, L.; Ricotti, M.; Vanoli, A.; Luinetti, O.; Dallera, E.; Riboni, R.; Paolucci, S.; Brugnatelli, S.; Paulli, M.; Pedrazzoli, P.; Baldanti, F.; Perfetti, V. Systematic analysis of human oncogenic viruses in colon cancer revealed EBV latency in lymphoid infiltrates. Infect. Agent. Cancer 2014, 9, 18.

17. Bjørge, T.; Hakulinen, T.; Engeland, A.; Jellum, E.; Koskela, P.; Lehtinen, M.; Luostarinen, T.; Paavonen, J.; Sapp, M.; Schiller, J.; Thoresen, S.; Wang, Z.; Youngman, L.; Dillner, J. A prospective, seroepidemiological study of the role of human papillomavirus in esophageal cancer in Norway. Cancer Res. 1997, 57, 3989-3992.

18. Zhang, S.K.; Guo, L.W.; Chen, Q.; Zhang, M.; Liu, S.Z.; Quan, P.L.; Lu, J.B.; Sun, X.B. The association between human papillomavirus 16 and esophageal cancer in Chinese population: a meta-analysis. BMC Cancer 2015, 15, 1096. 
19. Wang, X.; Tian, X.; Liu, F.; Zhao, Y.; Sun, M.; Chen, D.; Lu, C.; Wang, Z.; Shi, X.; Zhang, Q.; Zhang, D.; Shen, Z.; Li, F.; Harris, C.C.; Cai, H.; Ke, Y. Detection of HPV DNA in esophageal cancer specimens from different regions and ethnic groups: a descriptive study. BMC Cancer 2010, 10, 19.

20. Khoury, J.D.; Tannir, N.M.; Williams, M.D.; Chen, Y.; Yao, H.; Zhang, J.; Thompson, E.J.; TCGA Network, Meric-Bernstam, F.; Medeiros, L.J.; Weinstein, J.N.; Su, X. Landscape of DNA virus associations across human malignant cancers: analysis of 3,775 cases using RNA-Seq. J. Virol. 2013, 87, 8916-8926.

21. Parfenov, M.; Pedamallu, C.S.; Gehlenborg, N.; Freeman, S.S.; Danilova, L.; Bristow, C.A.; Lee, S.; Hadjipanayis, A.G.; Ivanova, E.V.; Wilkerson, M.D.; Protopopov, A.; Yang, L.; Seth, S.; Song, X.; Tang, J.; Ren, X.; Zhang, J.; Pantazi, A.; Santoso, N.; Xu, A.W.; Mahadeshwar, H.; Wheeler, D.A.; Haddad, R.I.; Jung, J.; Ojesina, A.I.; Issaeva, N.; Yarbrough, W.G.; Hayes, D.N.; Grandis, J.R.; El-Naggar, A.K.; Meyerson, M.; Park, P.J.; Chin, L.; Seidman, J.G.; Hammerman, P.S.; Kucherlapati, R; Cancer Genome Atlas Network. Characterization of HPV and host genome interactions in primary head and neck cancers. Proc. Natl. Acad. Sci. U. S. A. 2014, 111, 15544-15549.

22. Curado, M.P.; Hashibe, M. Recent changes in the epidemiology of head and neck cancer. Curr. Opin. Oncol. 2009, 21, 194-200.

23. Maden, C.; Beckmann, A.M.; Thomas, D.B.; McKnight, B.; Sherman, K.J.; Ashley, R.L.; Corey, L.; Daling, J.R. Human papillomaviruses, herpes simplex viruses, and the risk of oral cancer in men. Am. J. Epidemiol. 1992, 135, 1093-1102.

24. Bae, J.M. Human papillomavirus 16 infection as a potential risk factor for prostate cancer: an adaptive meta-analysis. Epidemiol. Health 2015, 37, e2015005.

25. Farhadi, A.; Behzad-Behbahani, A.; Geramizadeh, B.; Sekawi, Z.; Rahsaz, M.; Sharifzadeh, S. High-risk human papillomavirus infection in different histological subtypes of renal cell carcinoma. J. Med. Virol. 2014, 86, 1134-1144.

26. Mollerup, S.; Asplund, M.; Friis-Nielsen, J.; Kjartansdóttir, K.R.; Fridholm, H.; Hansen, T.A.; Herrera, J.A.R.; Barnes, C.J.; Jensen, R.H.; Richter, S.R.; Nielsen, I.B.; Pietroni, C.; Alquezar-Planas, D.E.; Rey-Iglesia, A.; Olsen, P.V.S.; Rajpert-De Meyts, E.; GrothPedersen, L.; von Buchwald, C.; Jensen, D.H.; Gniadecki, R.; Høgdall, E.; Langhoff, J.L.; Pete, I.; Vereczkey, I.; Baranyai, Z.; Dybkaer, K.; Johnsen, H.E.; Steiniche, T.; Hokland, P.; Rosenberg, J.; Baandrup, U.; Sicheritz-Pontén, T.; Willerslev, E.; Brunak, S.; Lund, O.; Mourier, T.; Vinner, L.; Izarzugaza, J.M.G.; Nielsen, L.P.; Hansen, A.J. High-Throughput Sequencing-Based Investigation of Viruses in Human Cancers by Multienrichment Approach. J. Infect. Dis. 2019, 220, 1312-1324.

27. Gewirtzman, A.; Bartlett, B.; Tyring, S. Epidermodysplasia verruciformis and human papilloma virus. Curr. Opin. Infect. Dis. 2008, 21, 141-146.

28. Ramoz, N.; Rueda, L.A.; Bouadjar, B.; Montoya, L.S.; Orth, G.; Favre, M. Mutations in two adjacent novel genes are associated with epidermodysplasia verruciformis. Nat. Genet. 2002, 32, 579-581.

29. Rakislova, N.; Saco, A.; Sierra, A.; Del Pino, M.; Ordi, J. Role of Human Papillomavirus in Vulvar Cancer. Adv. Anat. Pathol. 2017, 24, 201-214.

30. Dimberg, J.; Hong, T.T.; Skarstedt, M.; Löfgren, S.; Zar, N.; Matussek, A. Detection of cytomegalovirus DNA in colorectal tissue from Swedish and Vietnamese patients with colorectal cancer. Anticancer Res. 2013, 33, 4947-4950.

31. Chen, H.P.; Jiang, J.K.; Chen, C.Y.; Yang, C.Y.; Chen, Y.C.; Lin, C.H.; Chou, T.Y.; Cho, W.L.; Chan, Y.J. Identification of human cytomegalovirus in tumour tissues of colorectal cancer and its association with the outcome of non-elderly patients. J. Gen. Virol. 2016, 97, 2411-2420.

32. Chen, H.P.; Jiang, J.K.; Chan, C.H.; Teo, W.H.; Yang, C.Y.; Chen, Y.C.; Chou, T.Y.; Lin, C.H.; Chan, Y.J. Genetic polymorphisms of the human cytomegalovirus UL144 gene in colorectal cancer and its association with clinical outcome. J. Gen. Virol. 2015, 96, 3613-3623.

33. Song, L.B.; Zhang, X.; Zhang, C.Q.; Zhang, Y.; Pan, Z.Z.; Liao, W.T.; Li, M.Z.; Zeng, M.S. Infection of Epstein-Barr virus in colorectal cancer in Chinese. Ai Zheng 2006, 25, 1356-1360.

34. Awerkiew, S.; Bollschweiler, E.; Metzger, R.; Schneider, P.M.; Hölscher, A.H.; Pfister, H. Esophageal cancer in Germany is associated with Epstein-Barr-virus but not with papillomaviruses. Med. Microbiol. Immunol. 2003, 192, 137-140.

35. Martínez-López, J.L.; Torres, J.; Camorlinga-Ponce, M.; Mantilla, A.; Leal, Y.A. ; Fuentes-Pananá, E.M. Evidence of Epstein-Barr virus association with gastric cancer and non-atrophic gastritis. Viruses 2014, 6, 301-318.

36. Corallo, S.; Fucà, G.; Morano, F.; Salati, M.; Spallanzani, A.; Gloghini, A.; Volpi, C.C.; Trupia, D.V.; Lobefaro, R.; Guarini, V. ; Milione, M.; Cattaneo, L.; Antista, M.; Prisciandaro, M.; Raimondi, A.; Sposito, C.; Mazzaferro, V.; de Braud, F.; Pietrantonio, F.; Di Bartolomeo, M. Clinical Behavior and Treatment Response of Epstein-Barr Virus-Positive Metastatic Gastric Cancer: Implications for the Development of Future Trials. Oncologist 2020, 25, 780-786.

37. Li, W.; Wu, B.A.; Zeng, Y.M.; Chen, G.C.; Li, X.X.; Chen, J.T.; Guo, Y.W.; Li, M.H.; Zeng, Y. Epstein-Barr virus in hepatocellular carcinogenesis. World J. Gastroenterol. 2004, 10, 3409-3413.

38. Strong, M.J.; O'Grady, T.; Lin, Z.; Xu, G.; Baddoo, M.; Parsons, C.; Zhang, K.; Taylor, C.M.; Flemington, E.K. Epstein-Barr virus and human herpesvirus 6 detection in a non-Hodgkin's diffuse large B-cell lymphoma cohort by using RNA sequencing. J. Virol. 2013, 87, 13059-13062.

39. Nakhoul, H.; Lin, Z.; Wang, X.; Roberts, C.; Dong, Y.; Flemington, E. High-Throughput Sequence Analysis of Peripheral T-Cell Lymphomas Indicates Subtype-Specific Viral Gene Expression Patterns and Immune Cell Microenvironments. $m$ Sphere 2019, 4, e00248-19. 
40. Jalouli, J.; Jalouli, M.M.; Sapkota, D.; Ibrahim, S.O.; Larsson, P.A.; Sand, L. Human papilloma virus, herpes simplex virus and epstein barr virus in oral squamous cell carcinoma from eight different countries. Anticancer Res. 2012, 32, 571-580.

41. Goncalves, P.H.; Montezuma-Rusca, J.M.; Yarchoan, R.; Uldrick, T.S. Cancer prevention in HIV-infected populations. Semin. Oncol. 2016, 43, 173-188.

42. Narayanan, M.; Szymanski, J.; Slavcheva, E.; Rao, A.; Kelly, A.; Jones, K.; Jaffers, G. BK virus associated renal cell carcinoma: case presentation with optimized PCR and other diagnostic tests. Am. J. Transplant. 2007, 7, 1666-1671.

43. Abend, J.R.; Jiang, M.; Imperiale, M.J. BK virus and human cancer: innocent until proven guilty. Semin. Cancer Biol. 2009, 19, 252-260.

44. Shoraka, H.R.; Abobakri, O.; Naghibzade Tahami, A.; Mollaei, H.R.; Bagherinajad, Z.; Malekpour Afshar, R.; Shahesmaeili, A. Prevalence of JC and BK viruses in Patients with Colorectal Cancer: A Systematic Review and Meta- Analysis. Asian Pac. J. Cancer Prev. 2020, 21, 1499-1509.

45. Coelho, T.R.; Gaspar, R.; Figueiredo, P.; Mendonça, C.; Lazo, P.A.; Almeida, L. Human JC polyomavirus in normal colorectal mucosa, hyperplastic polyps, sporadic adenomas, and adenocarcinomas in Portugal. J. Med. Virol. 2013, 85, $2119-2127$.

46. Hori, R.; Murai, Y.; Tsuneyama, K.; Abdel-Aziz, H.O.; Nomoto, K.; Takahashi, H.; Cheng, C.M.; Kuchina, T.; Harman, B.V.; Takano, Y. Detection of JC virus DNA sequences in colorectal cancers in Japan. Virchows Arch. 2005, 447, 723-730.

47. Laghi, L.; Randolph, A.E.; Chauhan, D.P.; Marra, G.; Major, E.O.; Neel, J.V.; Boland, C.R. JC virus DNA is present in the mucosa of the human colon and in colorectal cancers. Proc. Natl. Acad. Sci. U. S. A. 1999, 96, 7484-7489.

48. Jung, W.T.; Li, M.S.; Goel, A.; Boland, C.R. JC virus T-antigen expression in sporadic adenomatous polyps of the colon. Cancer 2008, 112, 1028-1036.

49. Hashida, Y.; Nakajima, K.; Nakajima, H.; Shiga, T.; Tanaka, M.; Murakami, M.; Matsuzaki, S.; Naganuma, S.; Kuroda, N.; Seki, Y.; Katano, H.; Sano, S.; Daibata, M. High load of Merkel cell polyomavirus DNA detected in the normal skin of Japanese patients with Merkel cell carcinoma. J. Clin. Virol. 2016, 82, 101-107.

50. Moore, P.S.; Chang, Y. Why do viruses cause cancer? Highlights of the first century of human tumour virology. Nat. Rev. Cancer 2010, 10, 878-889.

51. Jin, F.; Vajdic, C.M.; Law, M.; Amin, J.; van Leeuwen, M.; McGregor, S.; Poynten, I.M.; Templeton, D.J.; Grulich, A.E. Incidence and time trends of anal cancer among people living with HIV in Australia. AIDS 2019, 33, 1361-1368.

52. Colón-López, V.; Shiels, M.S.; Machin, M.; Ortiz, A.P.; Strickler, H.; Castle, P.E.; Pfeiffer, R.M.; Engels, E.A. Anal Cancer Risk Among People With HIV Infection in the United States. J. Clin. Oncol. 2018, 36, 68-75.

53. Grew, D.; Bitterman, D.; Leichman, C.G.; Leichman, L.; Sanfilippo, N.; Moore, H.G.; Du, K. HIV Infection Is Associated With Poor Outcomes for Patients With Anal Cancer in the Highly Active Antiretroviral Therapy Era. Dis. Colon Rectum 2015, 58, 11301136.

54. Grulich, A.E.; van Leeuwen, M.T.; Falster, M.O.; Vajdic, C.M. Incidence of cancers in people with HIV/AIDS compared with immunosuppressed transplant recipients: a meta-analysis. Lancet 2007, 370, 59-67.

55. Hernández-Ramírez, R.U.; Shiels, M.S.; Dubrow, R.; Engels, E.A. Cancer risk in HIV-infected people in the USA from 1996 to 2012: a population-based, registry-linkage study. Lancet HIV 2017, 4, e495-e504.

56. Panfil, A.R.; Martinez, M.P.; Ratner, L.; Green, P.L. Human T-cell leukemia virus-associated malignancy. Curr. Opin. Virol. 2016, 20, 40-46.

57. Giam, C.Z.; Semmes, O.J. HTLV-1 Infection and Adult T-Cell Leukemia/Lymphoma-A Tale of Two Proteins: Tax and HBZ. Viruses 2016, 8, 161.

58. Zhou, Y.; Zhao, Y.; Li, B.; Huang, J.; Wu, L.; Xu, D.; Yang, J.; He, J. Hepatitis viruses infection and risk of intrahepatic cholangiocarcinoma: evidence from a meta-analysis. BMC Cancer 2012, 12, 289.

59. Su, F.H.; Le, T.N.; Muo, C.H.; Te, S.A.; Sung, F.C.; Yeh, C.C. Chronic Hepatitis B Virus Infection Associated with Increased Colorectal Cancer Risk in Taiwanese Population. Viruses 2020, 12, 97.

60. Iloeje, U.H.; Yang, H.I.; Jen, C.L.; Su, J.; Wang, L.Y.; You, S.L.; Lu, S.N.; Chen, C.J. Risk of pancreatic cancer in chronic hepatitis B virus infection: data from the REVEAL-HBV cohort study. Liver Int. 2010, 30, 423-429.

61. Hassan, M.M.; Li, D.; El-Deeb, A.S.; Wolff, R.A.; Bondy, M.L.; Davila, M.; Abbruzzese, J.L. Association between hepatitis B virus and pancreatic cancer. J. Clin. Oncol. 2008, 26, 4557-4562.

62. Tokita, H.; Murai, S.; Kamitsukasa, H.; Yagura, M.; Harada, H.; Takahashi, M.; Okamoto, H. High TT virus load as an independent factor associated with the occurrence of hepatocellular carcinoma among patients with hepatitis $\mathrm{C}$ virus-related chronic liver disease. J. Med. Virol. 2002, 67, 501-509.

63. Schildgen, V.; Malecki, M.; Tillmann, R.L.; Brockmann, M.; Schildgen, O. The Human Bocavirus Is Associated with Some Lung and Colorectal Cancers and Persists in Solid Tumors. PLoS One 2013, 8, e68020.

64. Höpken, M.; Förster, I.; Maune, S.; Brockmann, M.; Schildgen, O.; Schildgen, V. Association of the Human Bocavirus With Tonsil Squamous Cell Carcinomas. Front. Microbiol. 2018, 9, 2450.

65. Nakatsu, G.; Zhou, H.; Wu, W.K.K.; Wong, S.H.; Coker, O.O.; Dai, Z.; Li, X.; Szeto, C.H.; Sugimura, N.; Lam, T.Y.; Yu, A.C.; Wang, X.; Chen, Z.; Wong, M.C.; Ng, S.C.; Chan, M.T.V.; Chan, P.K.S.; Chan, F.K.L.; Sung, J.J.; Yu, J. Alterations in Enteric Virome Are Associated With Colorectal Cancer and Survival Outcomes. Gastroenterology 2018, 155, 529-541.e5. 
66. de Villiers, E.M.; Fauquet, C.; Broker, T.R.; Bernard, H.U.; zur Hausen, H. Classification of papillomaviruses. Virology 2004, 324, 17-27.

67. Doorbar, J.; Egawa, N.; Griffin, H.; Kranjec, C.; Murakami, I. Human papillomavirus molecular biology and disease association. Rev. Med. Virol. 2015, 25 Suppl 1, 2-23.

68. Buitrago-Pérez, A.; Garaulet, G.; Vázquez-Carballo, A.; Paramio, J.M.; García-Escudero, R. Molecular Signature of HPVInduced Carcinogenesis: pRb, p53 and Gene Expression Profiling. Curr. Genomics. 2009, 10, 26-34.

69. Emlet, C.; Ruffin, M.; Lamendella, R. Enteric Virome and Carcinogenesis in the Gut. Dig. Dis. Sci. 2020, 65, 852-864.

70. Braaten, K.P.; Laufer, M.R. Human Papillomavirus (HPV), HPV-Related Disease, and the HPV Vaccine. Rev. Obstet. Gynecol. 2008, 1, 2-10.

71. Norman, J.M.; Handley, S.A.; Baldridge, M.T.; Droit, L.; Liu, C.Y.; Keller, B.C.; Kambal, A.; Monaco, C.L.; Zhao, G.; Fleshner, P.; Stappenbeck, T.S.; McGovern, D.P.; Keshavarzian, A.; Mutlu, E.A.; Sauk, J.; Gevers, D.; Xavier, R.J.; Wang, D.; Parkes, M.; Virgin, H.W. Disease-specific alterations in the enteric virome in inflammatory bowel disease. Cell 2015, 160, 447-460.

72. Flynn, K.J.; Baxter, N.T.; Schloss, P.D. Metabolic and Community Synergy of Oral Bacteria in Colorectal Cancer. mSphere 2016, 1, e00102-16.

73. Hannigan, G.D.; Duhaime, M.B.; Ruffin, M.T. 4th; Koumpouras, C.C.; Schloss, P.D. Diagnostic Potential and Interactive Dynamics of the Colorectal Cancer Virome. mBio 2018, 9, e02248-18.

74. Davison, A.J.; Eberle, R.; Ehlers, B.; Hayward, G.S.; McGeoch, D.J.; Minson, A.C.; Pellett, P.E.; Roizman, B.; Studdert, M.J.; Thiry, E. The order Herpesvirales. Arch. Virol. 2009, 154, 171-177.

75. van Zyl, D.G.; Mautner, J.; Delecluse, H.J. Progress in EBV Vaccines. Front. Oncol. 2019, 9, 104.

76. Cai, Q.; Xiao, B.; Si, H.; Cervini, A.; Gao, J.; Lu, J. ; Upadhyay, S.K.; Verma, S.C.; Robertson, E.S. Kaposi's sarcoma herpesvirus upregulates Aurora A expression to promote p53 phosphorylation and ubiquitylation. PLoS Pathog. 2012, 8, e1002566.

77. Frazer, I.H. The actinic keratosis virome: can we prevent squamous cell carcinoma with a vaccine? Curr. Probl. Dermatol. 2015, $46,28-35$.

78. Cassler, N.M.; Merrill, D.; Bichakjian, C.K.; Brownell, I. Merkel Cell Carcinoma Therapeutic Update. Curr. Treat. Options Oncol. 2016, 17, 36.

79. Harms, P.W.; Harms, K.L.; Moore, P.S.; DeCaprio, J.A.; Nghiem, P.; Wong, M.K.K.; Brownell, I.; International Workshop on Merkel Cell Carcinoma Research (IWMCC) Working Group. The biology and treatment of Merkel cell carcinoma: current understanding and research priorities. Nat. Rev. Clin. Oncol. 2018, 15, 763-776.

80. Zhang, L.L.; Wie, J.Y.; Wang, L.; Huang, S.L.; Chen, J.L. Human T-cell lymphotropic virus type 1 and its oncogenesis. Acta Pharmacol. Sin. 2017, 38, 1093-1103.

81. Torresi, J.; Tran, B.M.; Christiansen, D.; Earnest-Silveira, L.; Schwab, R.H.M.; Vincan, E. HBV-related hepatocarcinogenesis: the role of signalling pathways and innovative ex vivo research models. BMC Cancer 2019, 19, 707.

82. McGivern, D.R.; Lemon, S.M. Virus-specific mechanisms of carcinogenesis in hepatitis C virus associated liver cancer. Oncogene 2011, 30, 1969-1983.

83. Matijašić, M.; Meštrović, T.; Paljetak, H.Č.; Perić, M.; Barešić, A.; Verbanac, D. Gut Microbiota beyond Bacteria-Mycobiome, Virome, Archaeome, and Eukaryotic Parasites in IBD. Int. J. Mol. Sci. 2020, 21, 2668.

84. Gilbert, J.A.; Blaser, M.J.; Caporaso, J.G.; Jansson, J.K.; Lynch, S.V.; Knight, R. Current understanding of the human microbiome. Nat. Med. 2018, 24, 392-400.

85. Carding, S.R.; Davis, N.; Hoyles, L. Review article: the human intestinal virome in health and disease. Aliment Pharmacol. Ther. 2017, 46, 800-815.

86. Carding, S.; Verbeke, K.; Vipond, D.T.; Corfe, B.M.; Owen, L.J. Dysbiosis of the gut microbiota in disease. Microb. Ecol. Health Dis. 2015, 26, 26191.

87. Tisza, M.J.; Buck, C.B. A catalog of tens of thousands of viruses from human metagenomes reveals hidden associations with chronic diseases. Proc. Natl. Acad. Sci. U. S. A. 2021, 118, e2023202118.

88. Suttle, C.A. Marine viruses--major players in the global ecosystem. Nat. Rev. Microbiol. 2007, 5, 801-812.

89. Roux, S.; Hallam, S.J.; Woyke, T.; Sullivan, M.B. Viral dark matter and virus-host interactions resolved from publicly available microbial genomes. Elife 2015, 4, e08490.

90. Handley, S.A.; Devkota, S. Going Viral: a Novel Role for Bacteriophage in Colorectal Cancer. mBio 2019, 10, e02626-18.

91. Stripling, J.; Rodriguez, M. Current Evidence in Delivery and Therapeutic Uses of Fecal Microbiota Transplantation in Human Diseases-Clostridium difficile Disease and Beyond. Am. J. Med. Sci. 2018, 356, 424-432

92. DePeters, E.J.; George, L.W. Rumen transfaunation. Immunol. Lett. 2014, 162, 69-76.

93. Broecker, F.; Kube, M.; Klumpp, J.; Schuppler, M.; Biedermann, L.; Hecht, J.; Hombach, M.; Keller, P.M.; Rogler, G.; Moelling, $\mathrm{K}$. Analysis of the intestinal microbiome of a recovered Clostridium difficile patient after fecal transplantation. Digestion 2013, 88, 243-251.

94. Fu, Y.; Luo, Y.; Grinspan, A.M. Epidemiology of community-acquired and recurrent Clostridioides difficile infection. Therap. Adv. Gastroenterol. 2021, 14, 17562848211016248.

95. Le Chatelier, E.; Nielsen, T.; Qin, J.; Prifti, E.; Hildebrand, F.; Falony, G.; Almeida, M.; Arumugam, M.; Batto, J.M.; Kennedy, S.; Leonard, P.; Li, J.; Burgdorf, K.; Grarup, N.; Jørgensen, T.; Brandslund, I.; Nielsen, H.B.; Juncker, A.S.; Bertalan, M.; Levenez, F.; 
Pons, N.; Rasmussen, S.; Sunagawa, S.; Tap, J.; Tims, S.; Zoetendal, E.G.; Brunak, S.; Clément, K.; Doré, J.; Kleerebezem, M.; Kristiansen, K.; Renault, P.; Sicheritz-Ponten, T.; de Vos, W.M.; Zucker, J.D.; Raes, J.; Hansen, T.; MetaHIT consortium; Bork, P.; Wang, J.; Ehrlich, S.D.; Pedersen, O. Richness of human gut microbiome correlates with metabolic markers. Nature 2013, 500, 541-546.

96. Youngster, I.; Russell, G.H.; Pindar, C.; Ziv-Baran, T.; Sauk, J.; Hohmann, E.L. Oral, capsulized, frozen fecal microbiota transplantation for relapsing Clostridium difficile infection. JAMA 2014, 312, 1772-1778.

97. Petrof, E.O.; Gloor, G.B.; Vanner, S.J.; Weese, S.J.; Carter, D.; Daigneault, M.C.; Brown, E.M.; Schroeter, K.; Allen-Vercoe, E. Stool substitute transplant therapy for the eradication of Clostridium difficile infection: 'RePOOPulating' the gut. Microbiome 2013, 1, 3 .

98. Mills, J.P.; Rao, K.; Young, V.B. Probiotics for prevention of Clostridium difficile infection. Curr. Opin. Gastroenterol. 2018, 34, 310.

99. Ott, S.J.; Waetzig, G.H.; Rehman, A.; Moltzau-Anderson, J.; Bharti, R.; Grasis, J.A.; Cassidy, L.; Tholey, A.; Fickenscher, H.; Seegert, D.; Rosenstiel, P.; Schreiber, S. Efficacy of Sterile Fecal Filtrate Transfer for Treating Patients With Clostridium difficile Infection. Gastroenterology 2017, 152, 799-811.e7.

100. Kao, D.H.; Roach, B.; Walter, J.; Lobenberg, R.; Wong, K. A51 Effect of lyophilized sterile fecal filtrate vs lyophilized donor stool on recurrent Clostridium difficile infection (RCDI): preliminary results from a randomized, double-blind pilot study. J. Can. Assoc. Gastroenterol. 2019, 2 (Issue Supplement 2), 101-102.

101. Zuo, T.; Wong, S.H.; Lam, K.; Lui, R.; Cheung, K.; Tang, W.; Ching, J.Y.L.; Chan, P.K.S.; Chan, M.C.W.; Wu, J.C.Y.; Chan, F.K.L.; $\mathrm{Yu}$, J.; Sung, J.J.Y.; $\mathrm{Ng}$, S.C. Bacteriophage transfer during faecal microbiota transplantation in Clostridium difficile infection is associated with treatment outcome. Gut 2018, 67, 634-643.

102. Broecker, F.; Russo, G.; Klumpp, J.; Moelling, K. Stable core virome despite variable microbiome after fecal transfer. Gut Microbes 2017, 8, 214-220.

103. Draper, L.A.; Ryan, F.J.; Smith, M.K.; Jalanka, J.; Mattila, E.; Arkkila, P.A.; Ross, R.P.; Satokari, R.; Hill, C. Long-term colonisation with donor bacteriophages following successful faecal microbial transplantation. Microbiome 2018, 6, 220.

104. Zitvogel, L.; Ma, Y.; Raoult, D.; Kroemer, G.; Gajewski, T.F. The microbiome in cancer immunotherapy: Diagnostic tools and therapeutic strategies. Science 2018, 359, 1366-1370.

105. Sharma, P.; Hu-Lieskovan, S.; Wargo, J.A.; Ribas, A. Primary, Adaptive, and Acquired Resistance to Cancer Immunotherapy. Cell 2017, 168, 707-723.

106. Davar, D.; Dzutsev, A.K.; McCulloch, J.A.; Rodrigues, R.R.; Chauvin, J.M.; Morrison, R.M.; Deblasio, R.N.; Menna, C.; Ding, Q.; Pagliano, O.; Zidi, B.; Zhang, S.; Badger, J.H.; Vetizou, M.; Cole, A.M.; Fernandes, M.R.; Prescott, S.; Costa, R.G.F.; Balaji, A.K.; Morgun, A.; Vujkovic-Cvijin, I.; Wang, H.; Borhani, A.A.; Schwartz, M.B.; Dubner, H.M.; Ernst, S.J.; Rose, A.; Najjar, Y.G.; Belkaid, Y.; Kirkwood, J.M.; Trinchieri, G.; Zarour, H.M. Fecal microbiota transplant overcomes resistance to anti-PD-1 therapy in melanoma patients. Science 2021, 371, 595-602.

107. Baruch, E.N.; Youngster, I.; Ben-Betzalel, G.; Ortenberg, R.; Lahat, A.; Katz, L.; Adler, K.; Dick-Necula, D.; Raskin, S.; Bloch, N.; Rotin, D.; Anafi, L.; Avivi, C.; Melnichenko, J.; Steinberg-Silman, Y.; Mamtani, R.; Harati, H.; Asher, N.; Shapira-Frommer, R.; Brosh-Nissimov, T.; Eshet, Y.; Ben-Simon, S.; Ziv, O.; Khan, M.A.W.; Amit, M.; Ajami, N.J.; Barshack, I.; Schachter, J.; Wargo, J.A.; Koren, O.; Markel, G.; Boursi, B. Fecal microbiota transplant promotes response in immunotherapy-refractory melanoma patients. Science 2021, 371, 602-609.

108. Pinato, D.J.; Howlett, S.; Ottaviani, D.; Urus, H.; Patel, A.; Mineo, T.; Brock, C.; Power, D.; Hatcher, O.; Falconer, A.; Ingle, M.; Brown, A.; Gujral, D.; Partridge, S.; Sarwar, N.; Gonzalez, M.; Bendle, M.; Lewanski, C.; Newsom-Davis, T.; Allara, E.; Bower, M. Association of Prior Antibiotic Treatment With Survival and Response to Immune Checkpoint Inhibitor Therapy in Patients With Cancer. JAMA Oncol. 2019, 5, 1774-1778.

109. Coley, W.B. The treatment of malignant tumors by repeated inoculations of erysipelas. With a report of ten original cases. Am. J. Med. Sci. 1893, 105, 487-511.

110. McCarthy, E.F. The toxins of William B. Coley and the treatment of bone and soft-tissue sarcomas. Iowa Orthop. J. 2006, 26, 154158.

111. Vétizou, M.; Pitt, J.M.; Daillère, R.; Lepage, P.; Waldschmitt, N.; Flament, C.; Rusakiewicz, S.; Routy, B.; Roberti, M.P.; Duong, C.P.; Poirier-Colame, V.; Roux, A.; Becharef, S.; Formenti, S.; Golden, E.; Cording, S.; Eberl, G.; Schlitzer, A.; Ginhoux, F.; Mani, S.; Yamazaki, T.; Jacquelot, N.; Enot, D.P.; Bérard, M.; Nigou, J.; Opolon, P.; Eggermont, A.; Woerther, P.L.; Chachaty, E.; Chaput, N.; Robert, C.; Mateus, C.; Kroemer, G.; Raoult, D.; Boneca, I.G.; Carbonnel, F.; Chamaillard, M.; Zitvogel, L. Anticancer immunotherapy by CTLA-4 blockade relies on the gut microbiota. Science 2015, 350, 1079-1084.

112. Routy, B.; Le Chatelier, E.; Derosa, L.; Duong, C.P.M.; Alou, M.T.; Daillère, R.; Fluckiger, A.; Messaoudene, M.; Rauber, C.; Roberti, M.P.; Fidelle, M.; Flament, C.; Poirier-Colame, V.; Opolon, P.; Klein, C.; Iribarren, K.; Mondragón, L.; Jacquelot, N.; Qu, B.; Ferrere, G.; Clémenson, C.; Mezquita, L.; Masip, J.R.; Naltet, C.; Brosseau, S.; Kaderbhai, C.; Richard, C.; Rizvi, H.; Levenez, F.; Galleron, N.; Quinquis, B.; Pons, N.; Ryffel, B.; Minard-Colin, V.; Gonin, P.; Soria, J.C.; Deutsch, E.; Loriot, Y.; Ghiringhelli, F.; Zalcman, G.; Goldwasser, F.; Escudier, B.; Hellmann, M.D.; Eggermont, A.; Raoult, D.; Albiges, L.; Kroemer, G.; Zitvogel, L. Gut microbiome influences efficacy of PD-1-based immunotherapy against epithelial tumors. Science 2018, 359, 91-97. 
113. Gopalakrishnan, V.; Spencer, C.N.; Nezi, L.; Reuben, A.; Andrews, M.C.; Karpinets, T.V.; Prieto, P.A.; Vicente, D.; Hoffman, K.; Wei, S.C.; Cogdill, A.P.; Zhao, L.; Hudgens, C.W.; Hutchinson, D.S.; Manzo, T.; Petaccia de Macedo, M.; Cotechini, T.; Kumar, T.; Chen, W.S.; Reddy, S.M.; Szczepaniak Sloane, R.; Galloway-Pena, J.; Jiang, H.; Chen, P.L.; Shpall, E.J.; Rezvani, K.; Alousi, A.M.; Chemaly, R.F.; Shelburne, S.; Vence, L.M.; Okhuysen, P.C.; Jensen, V.B.; Swennes, A.G.; McAllister, F.; Marcelo Riquelme Sanchez, E.; Zhang, Y.; Le Chatelier, E.; Zitvogel, L.; Pons, N.; Austin-Breneman, J.L.; Haydu, L.E.; Burton, E.M.; Gardner, J.M.; Sirmans, E.; Hu, J.; Lazar, A.J.; Tsujikawa, T.; Diab, A.; Tawbi, H.; Glitza, I.C.; Hwu, W.J.; Patel, S.P.; Woodman, S.E.; Amaria, R.N.; Davies, M.A.; Gershenwald, J.E.; Hwu, P.; Lee, J.E.; Zhang, J.; Coussens, L.M.; Cooper, Z.A.; Futreal, P.A.; Daniel, C.R.; Ajami, N.J.; Petrosino, J.F.; Tetzlaff, M.T.; Sharma, P.; Allison, J.P.; Jenq, R.R.; Wargo, J.A. Gut microbiome modulates response to anti-PD-1 immunotherapy in melanoma patients. Science 2018, 359, 97-103.

114. Matson, V.; Fessler, J.; Bao, R.; Chongsuwat, T.; Zha, Y.; Alegre, M.L.; Luke, J.J.; Gajewski, T.F. The commensal microbiome is associated with anti-PD-1 efficacy in metastatic melanoma patients. Science 2018, 359, 104-108.

115. Aarnoutse, R.; Ziemons, J.; Penders, J.; Rensen, S.S.; de Vos-Geelen, J.; Smidt, M.L. The Clinical Link between Human Intestinal Microbiota and Systemic Cancer Therapy. Int. J. Mol. Sci. 2019, 20, 4145.

116. Fluckiger, A.; Daillère, R.; Sassi, M.; Sixt, B.S.; Liu, P.; Loos, F.; Richard, C.; Rabu, C.; Alou, M.T.; Goubet, A.G.; Lemaitre, F.; Ferrere, G.; Derosa, L.; Duong, C.P.M.; Messaoudene, M.; Gagné, A.; Joubert, P.; De Sordi, L.; Debarbieux, L.; Simon, S.; Scarlata, C.M.; Ayyoub, M.; Palermo, B.; Facciolo, F.; Boidot, R.; Wheeler, R.; Boneca, I.G.; Sztupinszki, Z.; Papp, K.; Csabai, I.; Pasolli, E.; Segata, N.; Lopez-Otin, C.; Szallasi, Z.; Andre, F.; Iebba, V.; Quiniou, V.; Klatzmann, D.; Boukhalil, J.; Khelaifia, S.; Raoult, D.; Albiges, L.; Escudier, B.; Eggermont, A.; Mami-Chouaib, F.; Nistico, P.; Ghiringhelli, F.; Routy, B.; Labarrière, N.; Cattoir, V.; Kroemer, G.; Zitvogel, L. Cross-reactivity between tumor MHC class I-restricted antigens and an enterococcal bacteriophage. Science 2020, 369, 936-942.

117. Neil, J.A.; Cadwell, K. The Intestinal Virome and Immunity. J. Immunol. 2018, 201, 1615-1624.

118. Dzutsev, A.; Goldszmid, R.S.; Viaud, S.; Zitvogel, L.; Trinchieri, G. The role of the microbiota in inflammation, carcinogenesis, and cancer therapy. Eur. J. Immunol. 2015, 45, 17-31.

119. Zur Hausen, H.; Bund, T.; de Villiers, E.M. Infectious Agents in Bovine Red Meat and Milk and Their Potential Role in Cancer and Other Chronic Diseases. Curr. Top. Microbiol. Immunol. 2017, 407, 83-116.

120. Arroyo Mühr, L.S.; Bzhalava, Z.; Hortlund, M.; Lagheden, C.; Nordqvist Kleppe, S.; Bzhalava, D.; Hultin, E.; Dillner, J. Viruses in cancers among the immunosuppressed. Int. J. Cancer 2017, 141, 2498-2504.

121. Brunetti, C.R.; Amano, H.; Ueda, Y.; Qin, J.; Miyamura, T.; Suzuki, T.; Li, X.; Barrett, J.W.; McFadden, G. Complete genomic sequence and comparative analysis of the tumorigenic poxvirus Yaba monkey tumor virus. J. Virol. 2003, 77, 13335-13347.

122. Chehoud, C.; Dryga, A.; Hwang, Y.; Nagy-Szakal, D.; Hollister, E.B.; Luna, R.A.; Versalovic, J.; Kellermayer, R.; Bushman, F.D. Transfer of Viral Communities between Human Individuals during Fecal Microbiota Transplantation. mBio 2016, 7, e00322.

123. Brunse, A.; Deng, L.; Pan, X.; Hui, Y.; Castro-Mejía, J.L.; Kot, W.; Nguyen, D.N.; Secher, J.B.; Nielsen, D.S.; Thymann, T. Fecal filtrate transplantation protects against necrotizing enterocolitis. ISME J. 2021 [Epub ahead of print] 